\title{
MACROECONOMIC FACTORS ON NON-PERFORMING FINANCING IN INDONESIAN ISLAMIC BANK: ERROR CORRECTION MODEL APPROACH
}

\author{
Cyntia Ikramina ${ }^{a}$ \\ Puji Sucia Sukmaningrum ${ }^{\text {b }}$ \\ aslamic Economics Department, Faculty of Economics and Business, Universitas Airlangga \\ ${ }^{b}$ Islamic Economics Department, Faculty of Economics and Business, Universitas Airlangga \\ E-mail: cyntkrmn@gmail.com ${ }^{\text {a }}$; puji.sucia@feb.unair.ac.id ${ }^{\text {b }}$
}

ARTICLE HISTORY
Received:
8 December 2020
Revised
8 April 2021
Accepted:
31 May 2021
Online available:
30 June 2021
Keywords:
Non-Performing
financing,
Industrial Production
Index,
Inflation,
Rupiah Exchange Rate,
SBIS Return Rate.
*Correspondence:
Name:
Puji Sucia Sukmaningrum
E-mail:
puji.sucia@feb.unair.ac.id

\begin{abstract}
Non-performing Financing (NPF) is a ratio to measure the nonperforming finance level in Islamic banks and one indicator of Islamic banking's health. The higher NPF indicates the quality of the bank's financing was terrible. This study aims to determine several macroeconomic factors on the NPF ratio in Islamic commercial banks in Indonesia. This study applies Error Correction Model (ECM) with saturated sample methods. Sources of data from the official websites of the Financial Authority Services (OJK), Bank Indonesia (BI), and Indonesia Statistics Bureau (BPS). The sample used was Islamic commercial banks in all periods starting from January 2014 to February 2020 published in Islamic banking statistics. There are 74 Islamic commercial banks as observations. The results of this study are pretty surprising. In the short term, macroeconomic variables influence the NPF ratio in Islamic banks, while only inflation affects the NPF for a long time. The government needs to be more able to control when giving policies to increase inflation due to the impact of problematic Financing in Islamic banking. If it occurs continuously, the bank will threaten with bankruptcy. For the Islamic banking industry, we hoped that it could be wiser in placing the liquidity owned, especially when it comes to giving the financing, must carefully look at the customer's portfolio. This study provides comprehensive information on the macroeconomic impact on non-performing financing, specifically on Islamic banks in Indonesia.
\end{abstract}




\section{INTRODUCTION}

There is a reciprocal relationship between the Islamic banking industry and economic conditions in Indonesia. Current economic conditions can influence the growth of Islamic banking. On the other hand, Islamic banks also have a role in developing the financial system in Indonesia, based on Islamic law following the Prophet's Al-Quran and the hadiths.

A country can get the title of a developed country when the government can regulate its economy satisfactorily. Economic growth that is evenly distributed and continues to grow will able to prosper people. However, it cannot be separated from society's awareness always to work, achieve higher education, and develop technology. The measuring instrument that can see how advanced a country is GDP (Gross Domestic Product). According to Mankiw (2007), GDP is the market value of all final goods and services produced in a country at a particular time.

Adequacy of capital to start a business will increase productivity so that it will affect economic growth. However, sometimes people are worried about starting a business because they do not have enough capital. Islamic banks can become a solution to help them in channeling funds through financing products based on Islamic principles.

The increase in lending, or Financing in Islamic banks' terminology, affects the growth of assets owned by Islamic banks and the financing to deposit ratio (FDR). The ratio compares the bank's financing and the third-party fund (DPK). Islamic banks can provide an optimal role as intermediation if they successfully mobilized the fund, shown from the FDR level. Bank Indonesia has set a good standard for bank soundness, namely a minimum of $80 \%$ and a maximum of $110 \%$. An FDR level below $80 \%$ indicates that the bank cannot channel all the funds obtained from TPF to people who need loans. Meanwhile, the FDR ratio that exceeds the maximum limit of $110 \%$ explains that Islamic banks are too excessive in channeling loan funds. Both situations illustrate that Islamic banks do not perform their role as good intermediaries (Suryani, 2012).

Distribution of funds in the form of credit, which continues to increase compared to existing deposits in a bank, will increase the bank's risk (Mulyono, 1995). One of the dangers experienced by Islamic banks is credit risk or financing risk. Based on Financial Services Authority Circular Letter Number 10/SEOJK.03/2014, credit risk is the risk due to a customer or other party's failure to fulfill obligations to the bank following the agreed agreement. This risk is associated with financing or lousy credit, reflected by nonperforming Financing (NPF) in Islamic banking and non-performing loans (NPL) in conventional banks. The high ratio of NPF is also very risky for Islamic banks because it can affect their profitability. A study from Amzal (2016) reveals that NPF negatively affects the profit of Islamic banks. 
Table 1

Islamic Banks' Non-Performing Financing in Indonesia (2014 - 2020)

\begin{tabular}{llll}
\hline \multirow{2}{*}{ Year } & \multicolumn{3}{c}{ NPF } \\
\cline { 2 - 4 } & BUS & UUS & BPRS \\
\hline 2014 & $4.95 \%$ & $2.55 \%$ & $7.03 \%$ \\
2015 & $4.84 \%$ & $3.03 \%$ & $6.50 \%$ \\
2016 & $4.42 \%$ & $3.49 \%$ & $8.63 \%$ \\
2017 & $4.77 \%$ & $2.11 \%$ & $9.68 \%$ \\
2018 & $3.26 \%$ & $2.15 \%$ & $9.30 \%$ \\
2019 & $3.23 \%$ & $2.90 \%$ & $7.05 \%$ \\
Feb-2020 & $3.38 \%$ & $3.03 \%$ & $8.07 \%$ \\
\hline
\end{tabular}

Source: Financial Services Authority (Data Proceed)

Table 1 shows the level of the NPF ratio in the three Islamic banking industries in Indonesia. In 2014, Islamic commercial banks (BUS) had an NPF of 4.95\%, Islamic business units (UUS) of 2.55\%, and Islamic rural banks (BPRS) of 7.03\%. From 2014 to 2020, the Islamic commercial banks' NPF ratio was quite alarming as it was close to $5 \%$. Islamic rural bank is also very worried because it has a large percentage from 2014 to February. According to Bank Indonesia, the NPF ratio in Islamic banks is above $5 \%$, which will disturb the bank's health. Therefore, it should be solved so that there will be no greater risk.

Islamic commercial bank is a sharia bank that provides services through paid traffic. According to the Act on Bank Indonesia Regulation No. 11/3/PBI/2009, Islamic commercial bank has a Sharia Supervisory Board recommended by the Indonesian Ulema Council (MUI). Based on Table 1, the NPF in Islamic commercial banks has approached $5 \%$. Even though it improved in October 2018, Islamic commercial banks must prevent a high NPF by knowing the factors that determine NPF.

External factors are factors outside the bank that cannot be controlled by banking management and significantly affect debtors' ability to pay their installments (Rani, 2013). According to Firmansari and Suprayogi (2015), economic growth (GDP) substantially affects NPF at Islamic commercial banks and Islamic business units. It indicates that Islamic banks have not applied the principle of prudence in channeling financing when the country's economy is good, namely when GDP increases, the NPF ratio also increases. However, Ramanesty (2016); Škarica (2013) stated that an increasing GDP would decrease the NPF value. Haifa and Wibowo (2015) noted that inflation significantly affects NPF and is harmful to long-term calculations. However, inflation does not have a substantial impact on NPF in the short term.

Meanwhile, Ghosh (2015) stated that an increase in inflation would increase the NPL because income that does not increase and inflation will reduce the funds available 
to pay for loans. Not only inflation but Haifa and Wibowo (2015) stated that the exchange rate has a positive effect on NPF. It means that the exchange rate crisis is a proxy for monetary policy, making the company's ability worse by weakening its balance sheet, thereby reducing future investment. Meanwhile, Iriani and Yuliadi (2015) stated that the higher rupiah exchange rate impacted lower the NPF because increasing the exchange rate will increase the demand for local goods, increase domestic companies' income, and make it easier for them to pay financing or loans. The Certificate of Bank Indonesia (SBI) has a positive effect on conventional banks' NPL, revealed in a study by Poetry and Sanrego (2011). However, it is different from the Islamic Bank Indonesia Certificates (SBIS) rate of return. Research evidence conducted by Poetry and Sanrego (2011) stated that SBIS hurts the NPF of Islamic banks. According to the two types of banking's different characteristics, this difference is considered through mechanisms to return the debt. The SBI wear rate system does not care about the profit/loss from an investment. At the same time, SBIS uses contract ju'alah that does not harm any party.

The occurrence of problematic Financing or NPF has a long-term impact on the Islamic banking industry. The failure to achieve one of the Islamic banks' main functions, namely the lack of maximum financing for people who need funds for consumptive and productive activities. So that Islamic banks will find it challenging to develop, operate in moderation, and reduce customer trust so that they can make banks go bankrupt.

Therefore, based on fluctuations in non-performing financing in the field and gaps in research results, researchers are interested in further researching the determinants of the NPF ratio in Islamic commercial banks in Indonesia for the 20142018 periods.

\section{LITERATURE REVIEW}

As a financial intermediary, a bank is a financial institution that carries out money matters. Therefore, banks are always associated with facilitating human life in fulfilling their daily needs, especially in trade. An Islamic bank is a bank that operates without using interest, so it is called an interest-free bank. Operational and development of the products in Islamic banks based on the Al-Quran and the Hadith of the Prophet Muhammad. Meanwhile, an Islamic commercial bank is an Islamic bank with a role as a service provider in payment traffic. Islamic commercial banks can also act as foreign exchange banks or non-foreign exchange banks. A foreign exchange bank is a bank that can be a place for transactions abroad or those related to foreign currencies as a whole, for example, transfers abroad, opening letters of credit, and collection abroad.

Islamic bank funds come from core capital and third-party funds, which are deposits (wadiah) and quasi-equity (mudharabah accounts) (Machmud \& Rukmana, 2010). The products offered by Islamic banking in raising funds include savings, time 
deposits, and current accounts. Funds raised from third-party funds will be a channel for financing, following the bank's intermediary function. This function is manifest in channeling funds from people who have more funds to people who need funds. The use of bank funds follows in the Al-Quran letter At-Taubah verse 34, which reads, " $O$, believers! Indeed, many rabbis and monks consume people's wealth wrongfully and hinder others from the Way of Allah. Therefore, give the good news of a painful torment to those who hoard gold and silver and do not spend it in Allah's cases."

According to Ibn Kathir's interpretation, this verse describes the storage of assets. Assets may be kept as long as they are not intended for hoarding or avoid the obligation to give zakat because Allah strictly prohibits these two activities. However, when it has passed 12 months, humans are obliged to pay zakat from a portion of their assets to not get misery in the hereafter (Abdullah, 2003).

The risk of financing will arise when a bank cannot get back the principal or interest installments that have been loaned to customers or investments made; this is commonly known as problem financing. The demand to take advantage of excess liquidity is one reason banks efficiently provide loans or make investments. However, it can also occur because banks are not careful in anticipating various possible business risks they finance (Muhammad, 2011).

\section{Non Performing Financing}

Non-performing Financing (NPF) is a ratio that can measure the level of nonperforming financing that occurs in Islamic banks. Non-performing financing represents financing risk and directly impacts bank profitability (Effendi et al., 2017). The NPF ratio is determined by comparing the amount of non-performing financing with the total amount of financing distributed. After that, the NPF will be expressed as a percentage. Lousy credit or complex financing problems will affect a bank's soundness level, which almost all banks experience (Effendi et al., 2017).

\section{Industrial Production Index}

The industrial production index (IPI) is a monthly basis economic indicator to determine the size of actual output in industries in the fields of manufacturing, electricity, mining, and gas, which are relative to the base year. The IPI consists of the whole number of sub-indices that provide a detailed view of industry-specific output from all industries providing monthly production data (Kenton, 2021). Investors take advantage of IPI to see the fluctuations that occur in the industrial sector. IPI's monthly metrics will help investors find out about the output changes (Kenton, 2021). The retail 
industry in IPI is ignored. Otherwise, GDP measures end-users price, including the added value in the retail sector (Kenton, 2021).

The industrial production index is a proxy for GDP, where GDP is an indicator of economic growth which defines the good and bad financial performance of economic actors who have provided goods and services, including banking. Based on the research results by Akbar (2016); Ghosh (2015), the increasing level of GDP means that economic actors are in a good financial condition to make it easier to pay credit. Therefore, it can be concluded that increasing IPI will decrease the ratio of NPF at Islamic commercial banks.

\section{Inflation}

Bank Indonesia (2018) stated that inflation is a continuous increase in the price of an item that occurs widely and can cause other goods to rise in price, and not just one or two things. The inflation rate is the level of change in prices in general for various types of products within a specific time frame, for example, per month, quarterly, or per year (Murni, 2014).

When inflation increases, all prices of goods will experience an increase which occurs continuously. For producers, this is very detrimental because producers will find it challenging to get materials to produce goods, so that there may be a temporary halt in the production process. Furthermore, it is because the prices of input goods also rise so that production costs also increase. This difficulty will spread to the marketing that will be carried out, then the producer's income will decrease. Therefore, it will cause difficulties to pay loan installments to increase the NPF ratio in Islamic banks (Arjianto, 2010). Based on research by Ramanesty (2016), inflation has a positive and significant effect on NPF. In addition, Umar and Sun's (2018) research proved that inflation has a positive relationship to NPL. Therefore, it can be concluded that the increase in inflation will lead to a higher ratio of non-performing Financing in Islamic commercial banks.

\section{Rupiah Exchange Rate}

The exchange rate is the price of one currency measured in another currency. Some of the things that govern the exchange rate include interactions between households, government, companies, central banks, and private financial institutions. Exchange rates fluctuate to equalize the quantity of foreign currency demanded and supplied (McEachern, 2002). The demand for foreign exchange is caused by people who are not in their own country but have to adjust the currency in which they are located to get the necessities of life, such as investing and buying goods or services. Meanwhile, the supply of foreign exchange arises because of the desire of the public to exchange their country's currency for foreign currency to buy goods or services in that foreign currency. 
When the exchange rate increases or is commonly referred to as depreciation, the rupiah depreciation phenomenon will occur, which will make Bank Indonesia implement a policy to increase the Fasbis rate interest rate. As a result, the Islamic bank will reduce the expansion of financing so that the calculation of the NPF, where financing is a comparison, will cause the NPF to be higher (Soebagio, 2005). The higher the exchange rate will also cause an increase in interest expense so that the debtor will find it more challenging to repay the loan (Sutojo, 2000).

Based on the results of research by Umar and Sun (2018), an increasing exchange rate will cause an increase in NPL. In addition, Soebagio (2005) also stated that exchange rates have a positive effect on NPF. Therefore, it can be concluded that an increase in the rupiah exchange rate in foreign currencies will lead to a rise in non-performing Financing at Islamic commercial banks.

\section{SBIS Rate Return}

Bank Indonesia Islamic Certificates (SBIS) are securities issued by Bank Indonesia based on Islamic principles with a maturity of at least one month and a maximum of 12 months in the rupiah currency. The mechanism for issuing SBIS by Bank Indonesia uses an auction system with the Bank Indonesia-Scripless Securities Settlement System (BISSSS). This system is a means of transactions with Bank Indonesia, including the administration and administration of securities. The transactions are conducted electronically and directly connected between participants, the Bank Indonesia real-time gross settlement system, and operators.

Bank Indonesia Islamic Certificates are instruments owned by Bank Indonesia to control the country's monetary economy based on Sharia principles. Therefore, the greater the return offered by Bank Indonesia, the greater the interest of Islamic banks to carry out an agreement on SBIS, making the Financing that Islamic banks will issue decreases so that the risk of problematic financing is getting smaller (Poetry \& Sanrego, 2011).

The more negligible risk of non-performing financing reflects that the NPF ratio of Islamic banks will also be smaller. Therefore, it can be concluded that the higher the issued SBIS, the lower the ratio of non-performing Financing at Islamic commercial banks.

\section{Previous Study}

Magnitude in the influence of economic growth, inflation, actual effective exchange rates, unemployment rate, return on equity (ROE), capital adequacy ratio (CAR), bank age, bank size, political crisis, return on assets (ROA), net interest margin, 
bank time, money transfers, operational efficiency (INEF), political instability, and events external (global financial crisis) on the high NPL in the Fiji banking sector. The research was done during 2000-2013 by taking a sample of five commercial banks and two nonbank financial institutions. This study uses the ordinary least square analysis model, random effects, and fixed effects regression methods (Kumar et al., 2015).

Return on equity, capital adequacy ratio, bank size, unemployment rate, and bank time have a significant and negative effect on NPL. Net interest margin has a positive and significant impact on NPL. The inflation rate, operational efficiency, economic growth, inflation rate, exchange rate, and amount of money remittances had an insignificantly negative effect on NPL. On the other hand, the political crisis had a positive and insignificant impact on the NPL level. It is because the object of research is only small banks, not large banks.

Iriani and Yuliadi (2015) determined whether there is an influence of several macroeconomic variables on the level of NPF. These macroeconomic variables include inflation, exchange rates, the Jakarta Islamic Index (JII), Financing, and the money supply. The data used are secondary data from Islamic banking from January 2012 to April 2015, which amounted to 67 data observations-using the Vector Auto-Regressive (VAR) analysis method or the vector error correction model.

The results showed that more financing provided to debtors would increase credit risk at banks, meaning that financing has a positive and significant relationship to NPF. In contrast, the rupiah exchange rate and JII have a negative and significant effect on NPF. In addition, the increasing amount of money in circulation will cause high inflation. Therefore, Bank Indonesia will make a policy to lower interest rates. As a result, the act will stimulate the public to invest their money in Jll rather than spending it.

Umar and Sun (2018) analyzed the magnitude of macroeconomic and bankspecific factors on 197 registered and unregistered banks in China from 2005 to 2014. The data taken is secondary data from the financial position report and the related bank profit and loss statement. The macroeconomic variables used are the GDP growth rate, the effective interest rate, the inflation rate, and the foreign currency exchange rate. Meanwhile, bank-specific factors are bank spread, ROA, CAR, public debt to GDP ratio, bank operational efficiency, number of registered shareholders, gross credit growth, quality of bank loans, and diversification of ownership. The analysis method used is the fixed effect and the generalized method of moments (GMM) system estimation.

Bank spreads, effective interest rates, inflation rates, foreign exchange rates, and diversification of ownership have a positive and significant effect on NPLs. Meanwhile, GDP growth, bank loan quality, and CAR had a substantial and adverse impact on NPLs. However, the ratio of bank operational efficiency, ROA, and credit growth did not 
significantly affect NPL. It means that the reduction and risk-taking by the bank result in a lower NPL ratio.

\section{RESEARCH METHODS}

This research uses a quantitative approach to gain detailed information on the impaired financing's determinant in Islamic commercial banks. The analysis technique in this research uses Error Correction Model (ECM). The reason to use this model is its ability to analyze economic phenomena, whether in the short term or long term, and to study the consistency between the empirical and theoretical models (Widyawati \& Wahyudi, 2016).

The macroeconomics' monthly data, namely IPI and inflation in Indonesia, are sourced from the Indonesia Statistics Bureau (BPS) official report from January 2014 to February 2020. On the other hand, the exchange rate and SBIS rate of return variable also employ monthly data from January 2014 to February 2020. Both data obtained from Bank Indonesia official website, www.bi.go.id.

Table 2

The Secondary Data and Research's Data Source

\begin{tabular}{cc}
\hline Variable & Data Source \\
\hline Industrial Productin Index (IPI) & The Bureau of Statistics (www.bps.go.id) \\
Inflation & The Bureau of Statistics (www.bps.go.id) \\
Exchange Rate & Bank Indonesia (www.bi.go.id) \\
SBIS Rate of Return & Bank Indonesia (www.bi.go.id) \\
Non-Performing Financing (NPF) & The Financial Services Authority (www.ojk.go.id) \\
\hline
\end{tabular}

The population used in this study is the Islamic commercial bank, which is contained in the statistical reports of Islamic banking. The sampling technique used is saturated sampling. This technique is a sampling technique when all members of the population are used as samples. The sample used is the entire Islamic commercial bank published by Islamic banking statistics on the Financial Authority Services (OJK) website from January 2014 to February 2020.

\section{RESULT AND ANALYSIS}

\section{Stationarity Test}

The data stationarity test in this study used Augmented Dickey-Fuller (ADF) test statistic at the trend and intercept levels. The following are the results of the test at the class can be seen in the table below: 
Table 3

Results of Unit Root Test at Level of ADF Test Statistic

\begin{tabular}{lcccccc}
\hline \multirow{2}{*}{ Variable } & \multicolumn{6}{c}{ Unit Root Test } \\
\cline { 2 - 7 } & \multicolumn{2}{c}{ level } & \multicolumn{2}{c}{$\mathbf{1}^{\text {st }}$ difference } & \multicolumn{2}{c}{$\mathbf{2}^{\text {nd }}$ difference } \\
\cline { 2 - 7 } & ADF & prob & ADF & prob & ADF & Prob \\
\hline NPF & -1.79488 & 0.3801 & -3.51977 & 0.0102 & -17.2420 & 0.0001 \\
PI & -0.22868 & 0.9286 & -7.64570 & 0.0000 & -5.91398 & 0.0000 \\
Exchange Rate & -1.50362 & 0.5263 & -7.40594 & 0.0000 & -10.5327 & 0.0001 \\
Inflation & -6.2511 & 0.0000 & -6.84008 & 0.0000 & -8.01296 & 0.0000 \\
SBIS & -1.29182 & 0.6293 & -5.38236 & 0.0000 & -9.22937 & 0.0000 \\
\hline
\end{tabular}

Source: Eviews 9.0 Estimation Result (Processed Data)

Table 3 explains that not all variables are stationary at the level. In this study using $\alpha=5 \%$. Because several variables are not static, it is necessary to test for stationarity at the first difference level. With the aim, all variables can be free from unit root problems and have stationary data conditions. The table explains that all variables in this study are stationary at the first difference. Therefore, it can be concluded that at the first difference level, the variables NPF, IPI, inflation, rupiah exchange rate, and SBIS rate of return do not have a unit root, so the data is declared stationary.

\section{Optimal Lag Test}

Determination of the optimal lag is an essential step before proceeding to the cointegration test. Several criteria for selecting the optimal lag are Aike Information Criteria (AIC), Schwarz Criteria (SC), or Hannan-Quin Criterion (HQ). In selecting criteria, the researcher chooses the smallest criterion value of the three criteria.

Tabel 4

\begin{tabular}{ccccccc}
\multicolumn{7}{c}{ Lag Optimum Test } \\
\hline Lag & LogL & LR & FPE & AIC & SC & HQ \\
\hline 0 & -282.3182 & NA & 0.002528 & 8.209091 & 8.369698 & 8.272886 \\
1 & -11.66212 & 494.9140 & $2.27 \mathrm{e}-06^{\star}$ & 1.190346 & $2.153987^{\star}$ & $1.573116^{\star}$ \\
2 & 12.94374 & 41.47845 & $2.32 \mathrm{e}-06$ & 1.201607 & 2.968282 & 1.903352 \\
3 & 35.25549 & 34.42384 & $2.57 \mathrm{e}-06$ & 1.278415 & 3.848123 & 2.299134 \\
4 & 65.47899 & $42.31289^{\star}$ & $2.34 \mathrm{e}-06$ & $1.129172^{\star}$ & 4.501915 & 2.468866 \\
\hline
\end{tabular}

Source: Eviews 9.0 Estimation Result (Processed Data)

Table 4 shows the optimum lag test results, which will then be selected to continue the cointegration test. Based on the table above, the fixed optimal lag in this study is lag one because it has three stars between the others lag.

\section{Cointegration Test}

The cointegration test using Johansen's Cointegration test method by looking at the value of the trace statistic and the max eigen statistic. Which is must be greater than 
the critical value. The critical value used in the study is $5 \%$. If the variables are proven to be cointegrated, the VECM analysis model can be applied.

Table 5

Cointegration Test Results with The Johansen's Cointegration Test (Trace Statistic) Method

\begin{tabular}{lcccc}
\hline $\begin{array}{c}\text { Hypothesized } \\
\text { No. of CE(s) }\end{array}$ & Eigenvalue & Trace Statistic & $\begin{array}{c}\mathbf{5 \%} \\
\text { Critical Value }\end{array}$ & Prob.** \\
\hline None* & 0.582208 & 121.2117 & 69.81889 & 0.0000 \\
At most 1 & 0.355296 & 59.24493 & 47.85613 & 0.0030 \\
At most 2 & 0.235941 & 28.07849 & 29.79707 & 0.0779 \\
At most 3 & 0.112838 & 8.971679 & 15.49471 & 0.3680 \\
Atmost 4 & 0.006612 & 0.471044 & 3.841466 & 0.4925 \\
\hline
\end{tabular}

Source: Eviews 9.0 Estimation Result (Processed Data)

Table 5 shows that the trace statistic value at none is greater than the critical value of $5 \%$. Thus, it proves that the data in the research is cointegrated and indicates a long-term balance between variables. Furthermore, we can see the data cointegration in the max eigen statistic.

Table 6

Cointegration Test Results with The Johansen's Cointegration Test Method (Max Eigen Statistics)

\begin{tabular}{lcccc}
\hline $\begin{array}{l}\text { Hypothesized } \\
\text { No. of CE(s) }\end{array}$ & Eigenvalue & $\begin{array}{l}\text { Max Eigen } \\
\text { Statistic }\end{array}$ & $\begin{array}{l}\mathbf{5 \%} \\
\text { Critical Value }\end{array}$ & Prob.** \\
\hline None* & 0.582208 & 61.96679 & 33.87687 & 0.0000 \\
At most 1* & 0.355296 & 31.16644 & 27.58434 & 0.0166 \\
At most 2 & 0.235941 & 19.10681 & 21.13162 & 0.0938 \\
At most 3 & 0.112838 & 8.500635 & 14.26460 & 0.3301 \\
\hline
\end{tabular}

Source: Eviews 9.0 Estimation Result (Processed Data)

Table 6 shows the max eigen statistic test results where the value of the max eigen statistic is greater than the critical importance of $5 \%$ at none and most 1 . It means that the data is cointegrated and has a balance between variables in the long run. The cointegration of the data in Johanses's method shows that ECM use in the research is correct and can continue to the next test stage, namely ECM estimation.

\section{ECM Model Estimation}

Model estimation of this study using lag 1 to obtain the ECM estimation results. If the t-count value is greater than the t-table, then there is a significant relationship between exogenous variables and endogenous variables in the long or short term. The long-term and short-term estimation results are separate. Therefore, not all significant variables, in the long run, will have a considerable effect in the short term. 
Table 7

Error Correction Model Estimation

\begin{tabular}{llll}
\hline \multicolumn{3}{c}{ Long Term } & \\
\hline Variable & Coefficient & t-statistic & Information \\
\hline NPF & 1.000000 & - & - \\
IPI & -0.197981 & -0.95319 & Non-Significant \\
INFLATION & -36.64796 & -8.21012 & Significant \\
LNEXCHANGE_RATE & 2.498013 & 0.55637 & Non-Significant \\
SBIS & 1.609871 & 0.53801 & Non-Significant \\
\hline \multicolumn{3}{c}{ Short Term } & \\
\hline Variable & Coefficient & t-statistic & Information \\
\hline CointEq1 & -0.002790 & -0.84878 & Non- Significant \\
D(NPF(-1)) & -0.222181 & -1.70326 & Non- Significant \\
D(IPI(-1)) & -0.001414 & -0.20583 & Non- Significant \\
D(INFLATION(-1)) & -0.091719 & -0.90811 & Non- Significant \\
D(LNEXCHANGE-RATE(-1)) & -0.029957 & -0.01199 & Non- Significant \\
D(SBIS(-1)) & -0.199854 & 0.78483 & Non-Significant \\
\hline
\end{tabular}

Source: Eviews 9.0 Estimation Results (Data Processed)

Note: $t$-tabel $5 \%=1.99495$; $t$-table is obtained from the value $d f=n-k$ at $\alpha=5 \%$

Based on the ECM estimation results in Table 7, the long-term equation as follows:

$$
N P F_{t-1}=0.197981 I P I_{t-1}+36.64796 I N F_{t-1}-2.498013 L_{L N U R S}+1-1.609871 S_{\text {SBIS }}-1
$$

In the long run, inflation has a significant effect on NPF. It can be proved through Table 7, where the t-statistic value in the Inflation variable is $\mathbf{- 8 . 2 1 0 1 2}$ more significant than the t-table value, which is 1.99495 . The negative coefficient shows that when there is an increase in inflation of $1 \%$, it will cause a decrease in the NPF ratio of 36.64796 . Meanwhile, the IPI, rupiah exchange rate and the SBIS return rate did not significantly affect NPF. The t-statistic value of the IPI variable -0.95319 is smaller than the t-table value of 1.99495 . The LNKURS variable is 0.55637 , smaller than the t-table value of 1.99495. The SBIS variable has a t-statistic value of 0.53801 , smaller than the t-table value of 1.99495 .

Table 7 also shows the estimation results of the ECM in the short term. CointEq1 is the dependent variable Error Correction Term (ECT). Based on Table 7, the ECT is negative, meaning an adjustment from the short term to the long term with an error correction of -0.002790 . This figure explains that an error correction of 0.002790 is required to get to a long-term balance. For the next period, it will be even better so that the error will be lost.

In the short term, based on Table 7, all variables in the study do not have a significant effect on NPF. For example, the IPI variable has a t-statistic value -0.20583 , smaller than the t-table value of 1.99495 . Likewise, the inflation variable has a t-statistic 
of -0.90811 , smaller than the t-table value of 1.99495 . Likewise, the rupiah exchange rate variable (LNKURS) has a t-statistic of -0.01199 , smaller than the t-table of 1.99495 . And the SBIS rate of return variable has a t-statistic value -0.78483 smaller than the ttable value of 1.99495 .

\section{Analysis}

\section{The Effect of IPI on NPF}

IPI is a proxy for Gross Domestic Product (GDP). The results of this study are in line with research conducted by Purba and Darmawan (2018) that GDP has an insignificant effect on NPF. When economic growth rises, it indicates that the public's demand for consumptive and productive activities increases. The increase in the economy is directly proportional to the rise in people's income, thereby increasing the ability of debtors to repay their funds or loans. However, an increase in GDP is not always followed by a decrease in NPF. When people's income increases, the need tends to increase, giving rise to a consumptive attitude. Consumptive attitude causes the community to put aside their obligations as a debtor so that it impacts their ability to finance and results in an increase in NPF. The increasing level of the economy does not guarantee that the public will prioritize paying their obligations at the bank. Some people even tend to increase their consumption.

\section{The Effect of Inflation on NPF}

The results of this study are in line with the research conducted by Indrajaya (2019), Martiningsih (2014), Ramanesty (2016), Škarica (2013) stated that inflation has a significant and positive effect on NPF. It means that when inflation is increasing, the NPF ratio will also increase and vice versa. With the increase in inflation, it will decrease people's purchasing power so that the return that the company or seller will receive as a debtor will decrease. As a result of this decline in returns, it is difficult for companies to pay for financing provided by banks (Martiningsih, 2014). Another impact is given when inflation occurs, a decrease in the real income of the community, resulting in difficulties in paying obligations to banks because some of the payment has been used for daily needs (Martiningsih, 2014).

\section{The Effect of the Rupiah Exchange Rate on the NPF}

The results of this study are in line with research conducted by Firdaus (2016), Linda et al. (2015), Mutamimah and Chasanah (2012), which proved that the rupiah exchange rate does not have a significant effect on NPF. It means that when the rupiah exchange rate increases, it will cause the NPF ratio to increase, but it has no meaning. It 
is because customers do not feel the changes in the rupiah exchange rate. This situation occurs because changes in the rupiah exchange rate occur relatively in the short term so that this situation does not bother customers to make repayments of financing that have been made (Wijoyo, 2016). Changes in the rupiah exchange rate only affect when the customer is about to carry out murabahah financing, which is only at the beginning of the transaction. Because the price of the goods purchased is determined based on the cost of the goods on the market, when paying installments, it has been agreed from the beginning without considering changes in the rupiah exchange rate at a later date.

\section{The Effect of SBIS Rate of Return on NPF}

The results of this study are in line with research conducted by Poetry and Sanrego (2011), which proved that the SBIS reward level does not have a significant effect on the NPF ratio. Islamic monetary instruments are not only SBIS. Islamic banks can conduct transactions on the interbank market based on Islamic principles (PUAS) by using the tool of the Interbank Mudharabah Investment Certificate (IMA) (Muhammad, 2002). This investment is used to invest for banks with excess funds to reap profits and help banks with a shortage of funds. The amount of reward for the IMA certificate is calculated based on the agreed ratio.

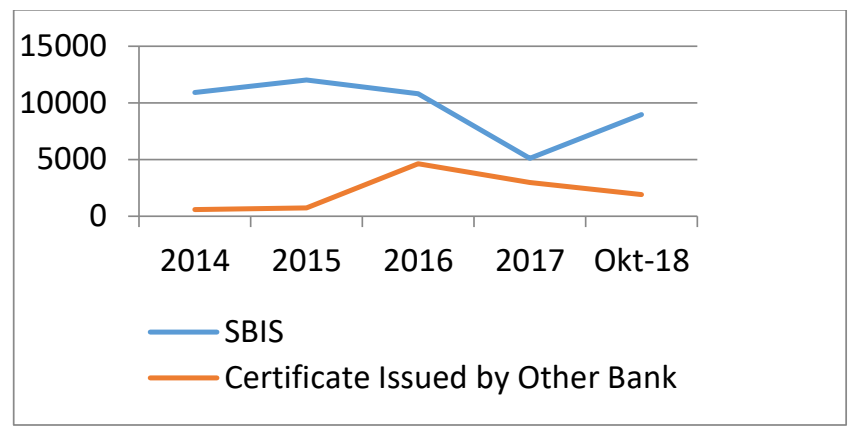

Figure 1. BUS's Certificates

Source: Financial Services Authority

\section{CONCLUSION}

Based on the results of the ECM estimate, it explains that inflation has a significant and positive effect on NPF. Meanwhile, the IPI, rupiah exchange rate and the SBIS imbalance did not significantly affect NPF in Islamic Commercial Banks in Indonesia for the 2014-2020 periods.

Suggestions that can be given to the government are to control better the formation of policies to increase inflation because of its impact on improving problematic Financing in Islamic banking, where the banks are continuously threatened with bankruptcy. For the Islamic banking industry, it is hoped that they can be wiser in 
placing the liquidity of their funds, especially when it comes to channeling financing. In addition, they must look at customer portfolios carefully. For future researchers, it is also necessary to examine the internal influence of Islamic banks on NPF due to the absence of mismanagement which is the basis for problematic financing. As well as identifying the types of contracts that cause financing problems, and it is hoped that banks will have the policy to respond to this.

\section{ACKNOWLEDGEMENT}

The research is part of the thesis by the author and under supervised by the coauthor. Thank you to our parents, family, and all academic members of the Faculty of Economics and Business, Universitas Airlangga, who have full support in working on this research.

\section{REFERENCES}

Abdullah. (2003). Tafsir Ibnu Katsir Jilid 3 (3rd ed.). Pustaka Imam Asy-Syafi"i.

Akbar, D. A. (2016). Inflasi, Gross Domestic Product (GDP), Capital Adequacy Ratio (CAR), dan Finance to Deposit Ratio (FDR) terhadap Non Performing Financing (NPF) pada Bank Umum Syariah di Indonesia. I-Economics, 2(2), 19-37. http://jurnal.radenfatah.ac.id/index.php/ieconomics/article/view/1021

Amzal, C. (2016). The Impact of Macroeconomic Variables on Indonesia Islamic Banks Profitability. Jurnal Ekonomi Dan Bisnis Islam, 2(1), 71-86. https://doi.org/10.20473/jebis.v2i1.1968

Arjianto, A. (2010). Etika Bisnis Bagi Pelaku Bisnis. Rajawali Pers.

Bank Indonesia. (2018). Pengenalan Inflasi. Bank Indonesia; Bank Indonesia. https://www.bi.go.id/id/fungsi-utama/moneter/inflasi/Default.aspx

Effendi, J., Thiarany, U., \& Nursyamsiah, T. (2017). Factors Influencing Non-Performing Financing (NPF) at Sharia Banking. Walisongo: Jurnal Penelitian Sosial Keagamaan, 25(1), 109-138. https://doi.org/10.21580/ws.25.1.1540

Firdaus, R. N. (2016). Pengaruh Faktor Internal dan Eksternal yang Mempempengaruhi Pembiayaan Bermasalah pada Bank Umum Syariah di Indonesia. El Dinar, 3(1), 82-108. https://doi.org/10.18860/ed.v3i1.3339

Firmansari, D., \& Suprayogi, N. (2015). Pengaruh Variabel Makroekonomi dan Variabel Spesifik Bank terhadap Non Performing Financing pada Bank Umum Syariah dan Unit Usaha Syariah di Indonesia Periode 2013-2014. Jurnal Ekonomi Syariah Teori Dan Terapan, 2(6), 512-520. https://doi.org/10.20473/vol2iss20156pp512-520

Ghosh, A. (2015). Banking-Industry Specific and Regional Economic Determinants of NonPerforming Loans: Evidence from US States. Journal of Financial Stability, 20, 93104. https://doi.org/10.1016/j.jfs.2015.08.004

Haifa, H., \& Wibowo, D. (2015). Pengaruh Faktor Internal Bank dan Makro Ekonomi Terhadap Non Performing Rasio Financing Perbankan Syariah di Indonesia: 
Periode 2010:01-2014:04. Jurnal Nisbah, 1(2), 74 -87.

https://doi.org/10.30997/jn.v1i2.253

Indrajaya, I. (2019). Determinan Non-Performing Financing pada Bank Umum Syariah di Indonesia. Jurnal Ekonomi Dan Bisnis Islam, 5(1), 68-81.

https://doi.org/10.20473/jebis.v5i1.13180

Iriani, L. D., \& Yuliadi, I. (2015). The Effect of Macroeconomic Variables on Non

Performance Financing of Islamic Banks in Indonesia. Economic Journal of

Emerging Markets, 7(2), 120-134. https://doi.org/10.20885/ejem.vol7.iss2.art5

Kenton, W. (2021). Industrial Production Index (IPI). Investopedia.

https://www.investopedia.com/terms/i/ipi.asp

Kumar, R. R., Stauvermann, P. J., Patel, A., \& Prasad, S. (2015). Determinants of NonPerforming Loans in Small Developing Economies : A Case of Fiji. Accounting Research Journal, 31(2), 192-213. https://doi.org/10.1108/ARJ-06-2015-0077

Linda, M. R., Megawati, M., \& Deflinawati, D. (2015). Pengaruh Inflasi, Kurs dan Tingkat Suku Bunga terhadap Non Performing Loan pada PT. Bank Tabugan Negara (Persero) Tbk Cabang Padang. Economica: Journal of Economic and Economic Education, 3(2), 137-145. https://doi.org/10.22202/economica.2015.v3.i2.251

Machmud, A., \& Rukmana, H. (2010). Bank Syariah, Teori, Kebajikan, dan Studi Empiris di Indonesia. Penerbit Erlangga.

Mankiw, G. (2007). Makroekonomi. Penerbit Erlangga.

Martiningsih, A. (2014). Analisis Pengaruh Sertifikat Bank Indonesia Syariah (SBIS), Nilai Tukar (Kurs), dan Inflasi terhadap Pembiayaan Bermasalah Perbankan Syariah di Indonesia Periode Juli 2010 - Desember 2013. Universitas Islam Negeri Syarif Hidayatullah Jakarta.

McEachern, W. (2002). Ekonomi Makro: Pendekatan Kontemporer. Salemba Empat. Muhammad, M. (2002). Manajemen Bank Syari'ah. Unit Penerbit dan Percetakan Sekolah Tinggi IImu Manajemen YKPN.

Muhammad, M. (2011). Manajemen Bank Syari'ah. Unit Penerbit dan Percetakan Sekolah Tinggi Ilmu Manajemen YKPN.

Mulyono, T. P. (1995). Analisis Laporan Keuangan Untuk Perbankan. Djambatan.

Murni, A. (2014). Ekonomika Makro. PT Refika Aditama.

Mutamimah, M., \& Chasanah, S. N. Z. (2012). Analisisi Eksternal dan Internal dalam Menentukan Non Performing Financing Bank Umum Syariah di Indonesia. Jurnal Bisnis Dan Ekonomi (JBE), 19(1), 49-64. https://unisbank.ac.id/ojs/index.php/fe3/article/view/1692

Poetry, Z. D., \& Sanrego, Y. D. (2011). Pengaruh Variabel Makro dan Mikro terhadap NPL Perbankan Konvensional dan NPF Perbankan Syariah. Tazkia Islamic Finance and Business Review, 6(2), 79-104. https://tifbrtazkia.org/index.php/TIFBR/article/view/53

Purba, N. S., \& Darmawan, A. (2018). Pengaruh Pertumbuhan Produk Domestik Bruto dan Inflasi Terhadap Non Performing Finance Bank Syariah. Jurnal Administrasi Bisnis (JAB), 61(2), 172.

http://administrasibisnis.studentjournal.ub.ac.id/index.php/jab/article/view/258 6 
Ramanesty, E. D. (2016). Pengaruh Struktur Pembiayaan, Inflasi, dan Pertumbuhan Ekonomi Terhadap Non Performing Financing Pada Bank Pembiayaan Rakyat Syariah di Jawa Barat Periode Tahun 2011 - 2015 [Universitas Airlangga]. http://repository.unair.ac.id/55713/

Rani, L. N. (2013). Analisis Faktor-Faktor Yang Mempengaruhi Non Performing Financing (NPF) Pada Perbankan Syariah di Indonesia (Periode Januari 2003 - Maret 2013) [Universitas Airlangga]. http://repository.unair.ac.id/39247/

Škarica, B. (2013). Determinants of Non-Performing Loans in Central and Eastern European Countries. Financial Theory and Practice, 38(1), 37-59. https://doi.org/10.3326/fintp.38.1.2

Soebagio, H. (2005). Analisis Faktor-Faktor yang Mempengaruhi Terjadinya Non Performing Loan (NPL) pada Bank Umum Komersial (Studi Empiris pada Sektor Perbankan di Indonesia). [Universitas Diponegoro]. http://eprints.undip.ac.id/11650/

Suryani, S. (2012). Analisis Pengaruh Financing to Deposit Ratio (FDR) terhadap Profitabilitas Perbankan Syariah di Indonesia. Economica: Jurnal Ekonomi Islam, 2(2), 153-170. https://doi.org/10.21580/economica.2012.2.2.854

Sutojo, S. (2000). Seri Manajemen Bank No. 6 - Strategi Manajemen Kredit Bank Umum: Konsep, Teknik dan Kasus. Damar Mulia Pustaka.

Umar, M., \& Sun, G. (2018). Determinants of Non-performing Loans in Chinese Banks. Journal of Asia Business Studies, 12(3), 273-289. https://doi.org/10.1108/jabs-012016-0005

Widyawati, S., \& Wahyudi, S. T. (2016). Determinan Pertumbuhan Kredit Modal Kerja Perbankan di Indonesia: Pendekatan Error Correction Model (ECM). Jurnal Keuangan Dan Perbankan, 20(1), 148-156. https://doi.org/10.26905/jkdp.v20i1.159

Wijoyo, S. (2016). Analisis Faktor Makroekonomi dan Kondisi Spesifik Bank Syariah terhadap Non-Performing Finance. Jurnal Pendidikan Dan Ekonomi, 5(6), 513525. https://eprints.uny.ac.id/43017/ 